\title{
ベースプレート下面側にリブ補強を施した鉄骨造露出型柱脚の構造性能 STRUCTURAL BEHAVIOR OF EXPOSED TYPE STEEL COLUMN BASE HAVING BASE PLATE WITH EMBEDDED RIB REINFORCEMENTS
}

\author{
萩野毅*, 原田幸博**, 渡辺亨***, 森田耕 次**** \\ Tsuyoshi HAGINO, Yukihiro HARADA, Toru WATANABE \\ and Koji MORITA
}

\begin{abstract}
We propose a new type of exposed steel column base with a base plate reinforced from underneath by rib plates embedded in the base concrete. A series of cyclic loading tests on actual-sized square tube column base specimens show that the combination of a short square stub column and rib plates arranged radially outside the stub column can effectively reinforce the base plate from underneath. Local behavior of the column base is estimated through plastic and finite element analyses; the findings of these analyses can be used for preventing local collapse and fracture of reinforced column bases.
\end{abstract}

Keywords : Rib Reinforcements , Exposed Type Steel Column Base, Structural Behavior リブ補強, 露出柱脚, 構造性能

\section{1. はじめに}

露出型柱脚において，柱脚に生じた曲げモーメントなどの応力は, ベースプレートを介してアンカーボルトの引張力とコンクリートヘ の圧縮力で基䃈柱型に伝達される。ここで，ベースプレートは，主 に面外一の曲げ抵抗によって力を伝達寸る。ベースプレートの面外 方向への曲げに対する剛性・耐力を確保するためには，板厚を大き く寸るかリブプレートによる補剛，補強を施す方法が考えられ，ベー スプレート上面に配置されたリブプレートに関する研究 ${ }^{122)}$ や設計法 3)もある。しかし，平板の板厚を大きくする方法は，柱外径が大きく なるに従い必要板厚が大きくなるため, 鋼材の入手が困難となる場 合がある。また，ベースプレート上面でリブプレートによって補強 寸る場合には, ベースプレートの板厚は抑えられるが, リブプレー トの大きさや枚数が増えることによって製作・加工が複雑になると 共に，アンカーボルトの配置も締付け工具の施工性確保のために大 きな制約を受けてしまう。ここで，リブプレートによる補強とアン カーボルト締付けに関する良好な施工性を両立させる方法の一つと して,リブプレートをベースプレート下面側に配して基礎コンクリー 卜内に納める工法が考えられる。

ベースプレート下面のリブ補強工法に関連する既往の研究として は，ベースプレート下面側に配されるシアプレートに関する研究 ${ }^{4)}$
が挙げられる。しかし，対象とされているシアプレートは柱外径よ りも小さくせん断抵抗能力のみを期待するものであり, 本研究で想 定するようなベースプレートの補強効果はないと考えられ，参考に なる知見は得がたい。

そこで本研究は角形鋼管柱の露出型柱脚を対象とし, まずべース プレート下面へのリブプレートによる補強方法について提案し，そ の有効性について実大柱脚実験で検証する。さらに, ベースプレー 卜構成部材の形状寸法をパラメータとした FEM 解析を行い, ベース プレート耐荷機構のモデル化とその検証を行う。

\section{2. ベースプレート下面側ヘのリブプレート補強方法}

本論文で扱うベースプレートとして，補強に係わる溶接量を少な くすることを考慮しつつアンカーボルトに対する面外曲げに有効と なるような補強方法と考え, ベースプレート下面に上面に取り付く 柱材と同じ外形を有する角形鋼管（以下，シアコラムと呼ぶ）を取 り付け，外側にむけてアンカーボルトを挟むように放射状にリブプ レートを配置した形状（図 1）とした。リブプレートは，内部に無収 縮モルタルを充填したシアコラムとベースプレートに垂直に取り付 けてベースプレートの面外変形を抑える役割を果たすもので，柱脚 の設計応力が大きくなりアンカーボルトの本数が増加する場合には

\begin{tabular}{cl}
\hline$*$ 旭化成建材侏) & Asahi Kasei Construction Materials Corporation \\
(千葉大学大学院工学研究科 博士後期課程) & (Graduate Student, Graduate School of Engineering, Chiba University) \\
$* * *$ 千葉大学大学院工学研究科 教授・博士 (工学) & Prof., Graduate School of Engineering, Chiba University, Dr. Eng. \\
*** 岡部(侏) 博士 (工学) & Okabe Corporation, Dr. Eng. \\
千**葉大学 名誉教授.工博 & Prof. Emeritus, Chiba University, Dr. Eng.
\end{tabular}




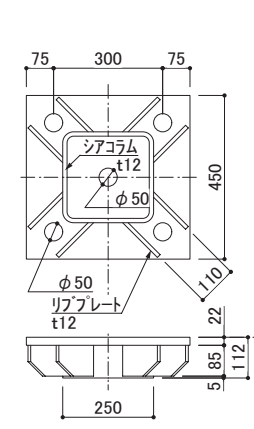

(a) $25-4 \mathrm{M} 36$

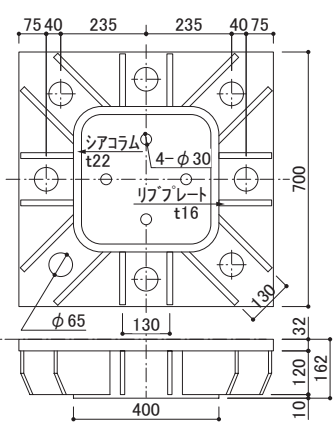

(b) $40-8 \mathrm{M} 48 \mathrm{U}$

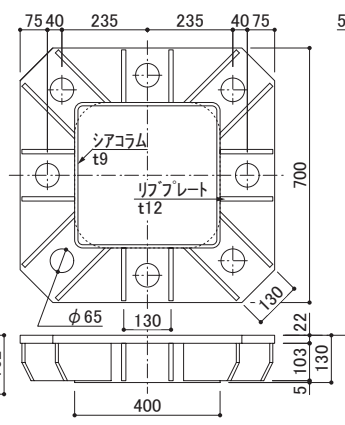

(c) 40-8M48D

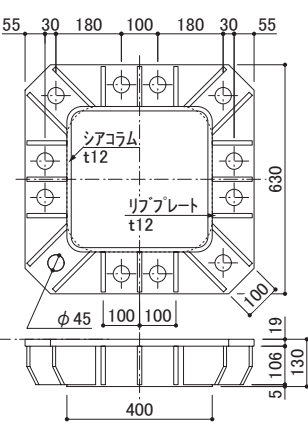

(d) $40-12 \mathrm{M} 36$

図 1 ベースプレート形状

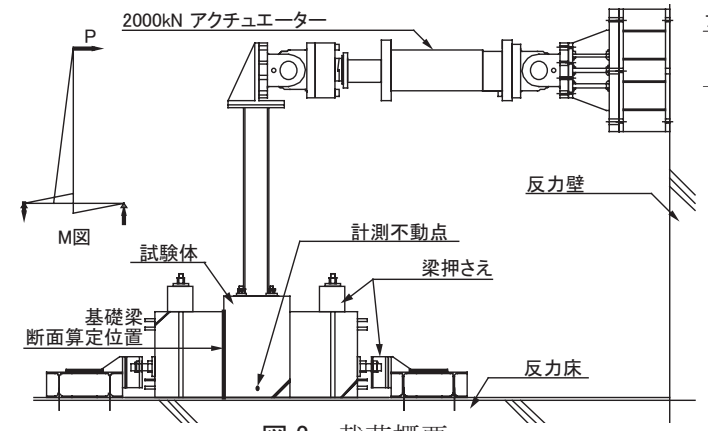

図 2 載荷概要

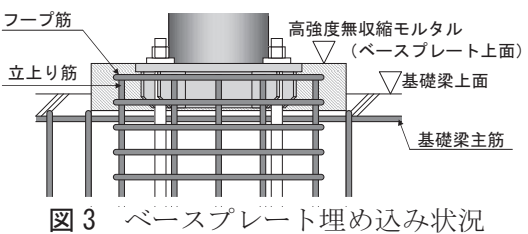

図 3 ベースプレード埋め込夕状況

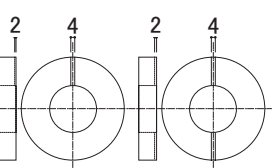

図 4 座金

径や本数の増加を考慮して柱外形寸法を $\square 400$ とし, M48アンカーボルト 8 本 でアンカーボルト耐力の上昇に合わせて ベースプレート構成要素の板厚や高さ を25-4M36 と比べ大幅に増加させた 40$8 \mathrm{M} 48 \mathrm{U}$, ベースプレート構成要素の板厚 が 25-4M36 とほぼ同一の 40-8M48D，ア ンカーボルトが M36 の 12 本でベースプ レートの板厚を25-4M36より小さくした 40-12M36 である。試験体一覧を表 1 に示 す。

使用する鉄骨柱は, 全塑性耐力がアン カーボルトの降伏を想定する柱脚モーメ ントの概ね 1.2 倍程度となる断面性能を 有する角形鋼管とし, 載荷点が 25-4M36 でベースプレート下面より $2250 \mathrm{~mm} ， 40-$ 8M48U で同じく2453mm, 40-8M48D と 40-12M36 で 2775mm と各試験体で異なる中で，弾性範囲に 留まるように板厚を設定した。

ベースプレートの形状寸法及びリブ補強形状を図 1 に示 す。柱材が $\square 400$ の試験体では, 柱角部に配置されたアン その枚数や板厚を増加させて対応する。なお, ベースプレートとシ アコラムとリブプレートはそれぞれ溶接によって接合するものとし， 溶接部における破壊を防ぐために完全溶込み溶接とした。

\section{3. 実大柱脚実験}

前章で提案した下面側にリブ補強したベースプレートについて有 効性を確認するとともに耐荷機構を検証するための実大柱脚実験を 実施する。

\section{1 載荷概要}

実大柱脚実験に用いる試験体は，基礎コンクリートにアンカーボ ルトを介して，ベースプレートを接合した鉄骨柱が固定された形状 とした。試験体の基礎コンクリートを反力床に固定し, 鉄骨柱頂部 に取り付けた $2000 \mathrm{kN}$ アクチュエーターによって正負交番繰り返しの 曲げとせん断を柱脚部に加えた（図 2)。また, 制御方法は載荷点位 置での水平変位量をベースプレート下面より載荷点までの高さで除 した部材角の変位制御とし $, \pm 1 / 800, \pm 1 / 400, \pm 1 / 200, \pm 1 / 100 \mathrm{rad}$ の順 に最終目標 $+1 / 10 \mathrm{rad}$ まで各 1 回ずつ載荷を行う。

\section{2 実大柱脚試験体概要}

試験体は, 柱外形寸法が $\square 250$ でM36アンカーボルトを柱角部 にそれぞれ配置した 25-4M36, 柱の大径化に伴うアンカーボルトの

表 1 実大柱脚実験試験体一覧

\begin{tabular}{|c|c|c|c|c|}
\hline 試験体名 & $\begin{array}{l}\text { 柱サイズ } \\
\text { (材質) }\end{array}$ & \begin{tabular}{|c|} 
アンカーボルト \\
本数-祸"径
\end{tabular} & \begin{tabular}{|c} 
基礎柱型寸法 \\
(mm)
\end{tabular} & 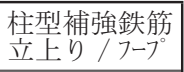 \\
\hline 25-4M36 & & 4-M36 & $650 \times 650$ & \begin{tabular}{|l|l|} 
20-D22 \\
D13@100
\end{tabular} \\
\hline & $\begin{array}{c}\square 400 \times 400 \times 22 \\
(\mathrm{BCP} 325)\end{array}$ & 8-M48 & $950 \times 950$ & $\begin{array}{l}\text { 24-D25 } \\
\text { D13@100 }\end{array}$ \\
\hline 40-8M48D & $\begin{array}{c}\square 400 \times 400 \times 25 \\
(\mathrm{BCP} 325)\end{array}$ & 8-M48 & $1000 \times 1000$ & $\begin{array}{l}32-\mathrm{D} 25 \\
/ \text { D16@100 }\end{array}$ \\
\hline $40-12 \mathrm{M} 36$ & $\begin{array}{c}\square 400 \times 400 \times 25 \\
(\mathrm{BCP} 325)\end{array}$ & $12-\mathrm{M} 36$ & $830 \times 830$ & $\begin{array}{l}\text { 24-D25 } \\
/ \text { D16@100 }\end{array}$ \\
\hline
\end{tabular}
カーボルトを角部柱面に近くなるよう配置しており, 中間に配置さ れたアンカーボルトと柱フランジ面からの距離が異なる。また, リ ブプレートの下端角部は, 基礎コンクリートへの応力集中を緩和す るためにリブプレート高さに対して約半分の寸法で隅切りを施して いる。また, ベースプレート下面のリブプレート等は基礎梁の主筋 との干渉を避けなければならない。従って, ベースプレート下端は 基礎梁主筋の上端より上で，コンクリートの打設を基礎梁の上端ま でとするが，基礎柱型の主筋及びフープ筋をベースプレート上面近 くまで配置する。コンクリート上面に, ベースプレート下面高さに シアコラム内側に納まるレベルモルタルを作製して柱建方を行い, 基礎柱型の大きさで型枠を作製し, 流動性の高い高強度無収縮モル タルをベースプレート上面まで打設する（図 3)。

ベースプレート下面は複雑な形状であるが，空気抜きを目的とし た孔を設ける（図 1）ことによって，無収縮モルタルはベースプレー 卜下面と基礎柱型上面の隙間に充填され, 基礎柱型と鉄骨柱の密着 性が確保される。また, アンカーボルトの座金にも空気抜きの溝を 設け（図 4), ベースプレートとアンカーボルトとのクリアランスに も無収縮モルタルが充填される。ただし，40-8M48D と 40-12M36で はベースプレートに空気孔を設けず，事前にシアコラム側にグラウ 卜を充填した後, 柱建方を行っている。

アンカーボルトは, 全試験体で高張力丸鋼（規格降伏点 $600 \mathrm{~N} /$ $\mathrm{mm}^{2}$ ) を用い, 定着板を介して基礎柱型内に定着される。アンカー ボルトの基礎柱型への埋め込み深さは, 25-4M36 で基礎梁上面から 350mm，40-8M48U で基礎梁上面から $567 \mathrm{~mm}$ としたが，アンカーボ ルトを鉄筋で補強された基礎柱型により十分に埋め込む必要がある と考え，40-8M48D と 40-12M36では基礎柱型補強鉄筋量を増やす と共に, 基礎梁上面からの埋め込み深さを M48 で 700mm, M36で $600 \mathrm{~mm}$ とし, さらに定着板とアンカーボルト位置保持を目的とした 定着フレームで基礎柱型に定着させた。各試験体の基礎コンクリー 


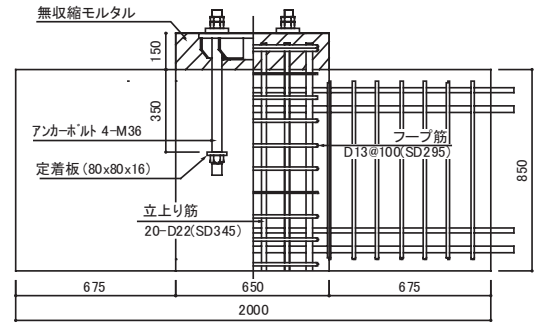

(a) 25-4M36

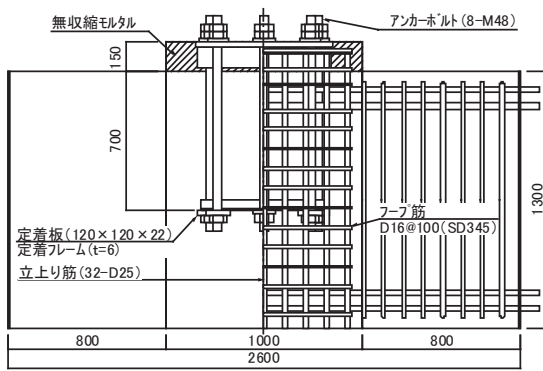

(c) $40-8 \mathrm{M} 48 \mathrm{D}$

図 5 試験体基礎コンクリート部仕様

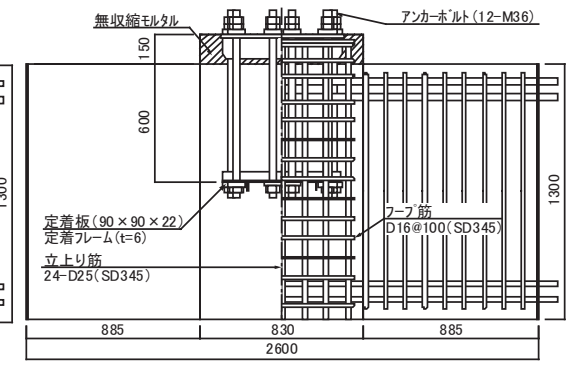

(d) $40-12 \mathrm{M} 36$

表 2 主要部材の機械的性質

$\left(\mathrm{N} / \mathrm{mm}^{2}\right)$

\begin{tabular}{|c|c|c|c|c|}
\hline $\begin{array}{c}\text { 主要 } \\
\text { 構成部材 } \\
\end{array}$ & $\begin{array}{l}\text { 形状寸法 } \\
\text { (試験体) }\end{array}$ & 材質 & 降伏点 & 引張強さ \\
\hline \multirow{4}{*}{$\begin{array}{l}\text { アンカー } \\
\text { ボルト }\end{array}$} & M36 (4M36) & \multirow{4}{*}{$\begin{array}{c}\text { 高張力 } \\
\text { 丸鋼 }\end{array}$} & 616 & 934 \\
\hline & M48 (8M48U) & & 639 & 979 \\
\hline & M48 (8M48D) & & 633 & 965 \\
\hline & M36（12M36） & & 669 & 994 \\
\hline \multirow{4}{*}{$\begin{array}{l}\text { ベース } \\
\text { プレート }\end{array}$} & t22 (4M36) & \multirow{4}{*}{ SN490B } & 370 & 538 \\
\hline & $\mathrm{t} 32$ (8M48U) & & 356 & 525 \\
\hline & t22 (8M48D) & & 389 & 542 \\
\hline & t19 (12M36) & & 361 & 535 \\
\hline \multirow{3}{*}{ プリブ } & $\mathrm{t} 12$ (4M36) & \multirow{3}{*}{ SN490B } & 364 & 527 \\
\hline & t16 (8M48U) & & 389 & 529 \\
\hline & $\begin{array}{rr}\mathrm{t} 12 \quad(8 \mathrm{M} 48 \mathrm{D} \\
& , 12 \mathrm{M} 36) \\
\end{array}$ & & 349 & 515 \\
\hline \multirow{4}{*}{$\begin{array}{l}\text { シア } \\
\text { コラム }\end{array}$} & $\mathrm{t} 12 \quad(4 \mathrm{M} 36)$ & BCR295 & 404 & 472 \\
\hline & t22 (8M48U) & BCP325 & 376 & 522 \\
\hline & t9 (8M48D) & \multirow{2}{*}{ BCR295 } & 337 & 437 \\
\hline & t12 (12M36) & & 350 & 440 \\
\hline
\end{tabular}

表 3 基礎コンクリートと無収縮モルタルの圧縮強度（ $\left.\mathrm{N} / \mathrm{mm}^{2}\right)$

\begin{tabular}{|c|c|c|}
\hline 試験体名 & 基礎コンクリート & 無収縮モルタル \\
\hline $25-4 \mathrm{M} 36$ & 24 & 69 \\
\hline $40-8 \mathrm{M} 48 \mathrm{U}$ & 36 & 56 \\
\hline $40-8 \mathrm{M} 48 \mathrm{D}$ & 31 & 69 \\
\hline $40-12 \mathrm{M} 36$ & 33 & 68 \\
\hline
\end{tabular}

卜部の仕様を図 5 に示す。なお, 基礎柱型の主筋断面は, 柱型断面 に対して最大が 25-4M36 の $1.83 \%$ ，最小で 40-8M48Uの $1.35 \%$ とな っている。これは，柱脚降伏耐力時に想定する引張側アンカーボル 卜の総引抜力に対して，全主筋引張耐力がそれぞれ約 $250 \% ， 110 \%$

表 4 実験結果一覧

$(\mathrm{kN} \cdot \mathrm{m})$

\begin{tabular}{|c|c|c|c|c|}
\hline 試験体 & \multicolumn{2}{|c|}{$\begin{array}{l}\text { 柱脚降伏 } \\
\text { モーメント }\end{array}$} & モピン & 最終状況 \\
\hline $25-4 \mathrm{M} 36$ & 369 & -356 & 444 & 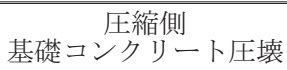 \\
\hline $40-8 \mathrm{M} 48 \mathrm{U}$ & 1,773 & $-1,745$ & 1,977 & アンカーボルト抜出し \\
\hline 40-8M48D & 1,586 & $-1,516$ & 1,680 & ベースプレート破断 \\
\hline 40-12M36 & 1,353 & $-1,381$ & 1,742 & ベースプレート破断 \\
\hline
\end{tabular}

となる鉄筋量である。さらに基礎梁は柱材全塑性 耐力の 1.5 倍の曲げモーメントがベースプレート 上面に生じた時に，図 2 に示す柱型フェイスにお いて曲げ降伏かつせん断降伏しないこととして鉄 筋量を定めている。

実験に使用したアンカーボルト， ベースプレー 卜を構成する鋼材の機械的性質を表 2 に, 基礎コ ンクリートと無収縮モルタルの圧縮強度を表 3 に 示す。

\section{3 実験結果}

各試験体の実験結果を表 4 に，柱脚部モーメン 卜 $M$ と柱脚回転角 ${ }_{B} \theta$ の関係 $\left(M-{ }_{B} \theta\right.$ 関係）を図 6 に示す。ここで, 柱脚回転角は図 2 に示す試験体 基礎柱型基部を不動点とする鉄骨柱基部に設置し た変位計を用いて求めたもので，履歴曲線上のの 印は，表 4 に示す柱脚降伏モーメントである。こ の柱脚降伏モーメントは図 7 に示すアンカーボル トに貼り付けていたひずみゲージの值から判断し たもので，引張側第 1 列目アンカーボルトの全てが素材試験結果の 降伏ひずみに達した時のモーメントである。

各試験体の最終状況は，25-4M36 は繰返し載荷による基礎コンク リートの劣化による耐力低下，40-8M48U はアンカーボルト降伏後に 柱脚回転角が $0.04 \mathrm{rad}$ を超えた後にアンカーボルトが抜け出し耐力低 下を生じた。40-8M48D,40-12M36 は，いずれもアンカーボルト降伏 以降に柱角部からベースプレートが破断した。（図 8)

柱脚部モーメントとベースプレート変形との関係を包絡線で表し
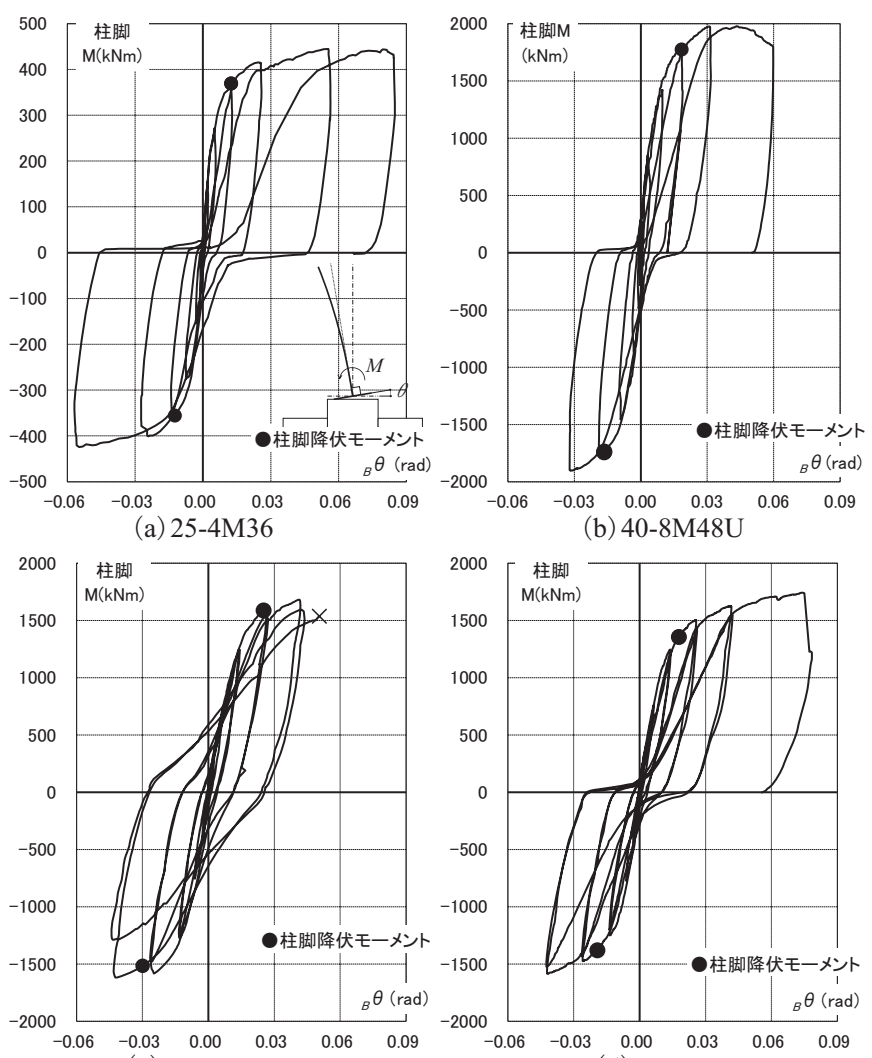

(c) $40-8 \mathrm{M} 48 \mathrm{D}$

(d) $40-12 \mathrm{M} 36$

図 6 柱脚部モーメント $M$ と柱脚回転角 ${ }_{B} \theta$ の関係 


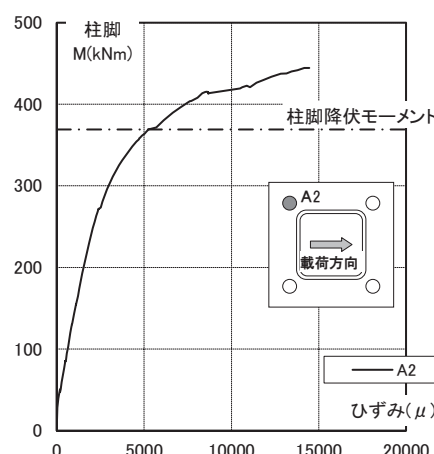

(a) $25-4 \mathrm{M} 36$

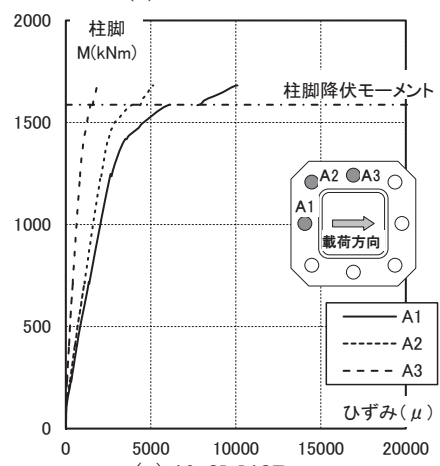

(c) 40-8M48D

図 7 柱脚部モーメント $M$ とアンカーボルトひずみの関係（包絡線）

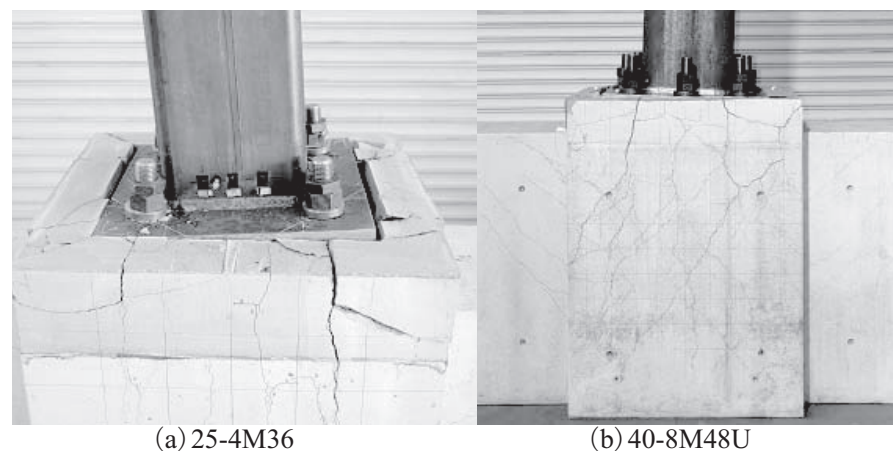

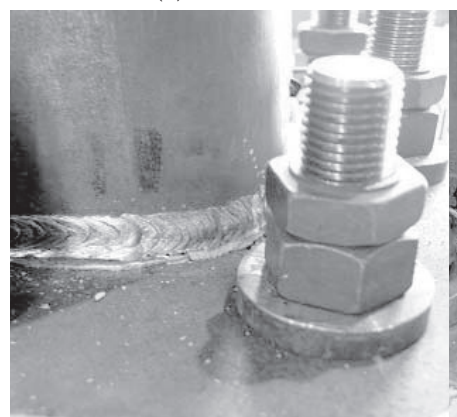

(c) 40-8M48D

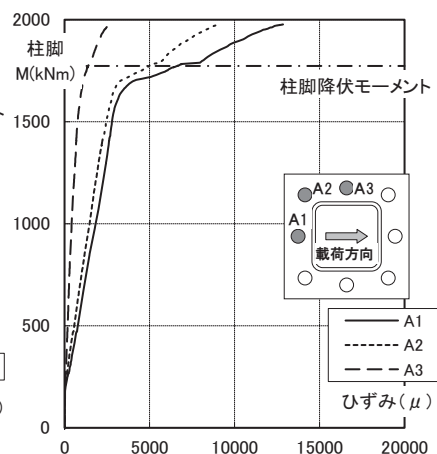

(b) $40-8 \mathrm{M} 48 \mathrm{U}$

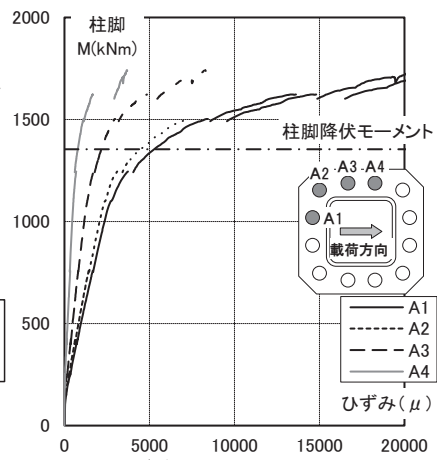

(d) $40-12 \mathrm{M} 36$

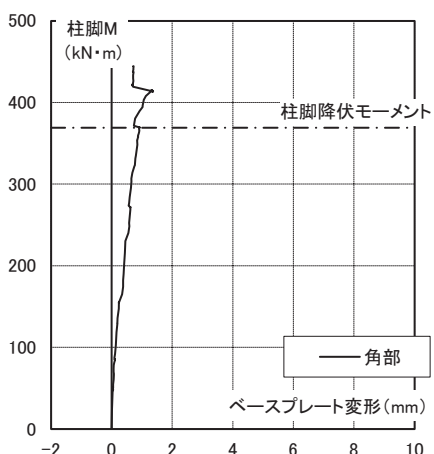

(a) $25-4 \mathrm{M} 36$

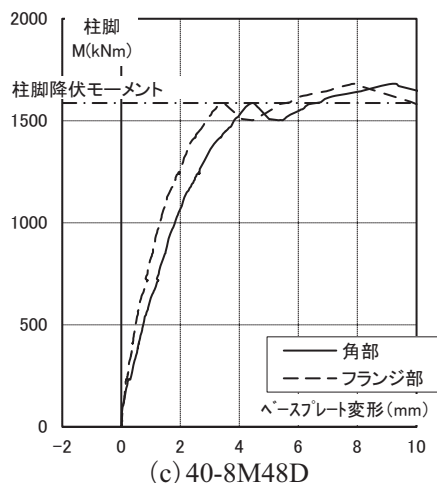

(c) 40-8M48D

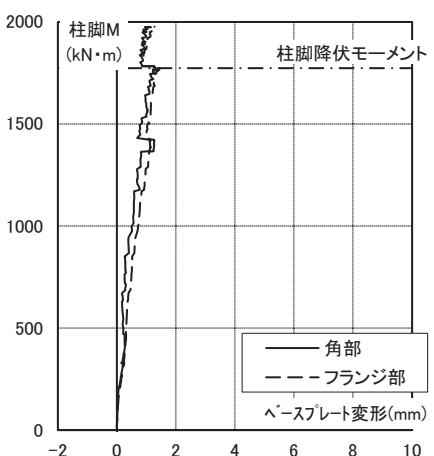

(b) $40-8 \mathrm{M} 48 \mathrm{U}$

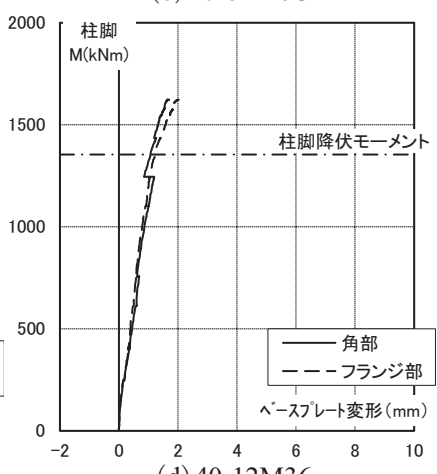

(d) 40-12M36
図 9 柱脚部モーメント $M$ とベースプレート変形 $\delta b$ の関係

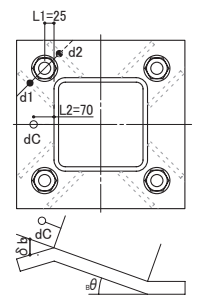

(a) $25-4 \mathrm{M} 36$

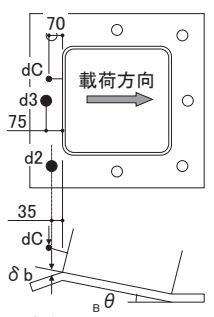

(b) $40-8 \mathrm{M} 48 \mathrm{U}$

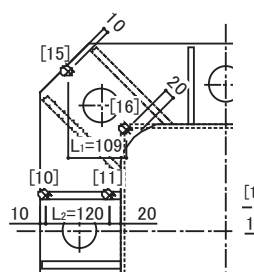

(c) $40-8 \mathrm{M} 48 \mathrm{D}$

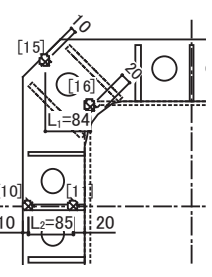

(d) $40-12 \mathrm{M} 36$
図 10 ベースプレート変形抽出に用いた変位計

$$
\text { フランジ部 : } \delta b=d C-{ }_{B} \theta \times 70+{ }_{B} \theta \times 75-d 3
$$

40-8M48D, 40-12M36 は柱角部と柱フランジ部それぞれで図 10 (c) (d) に示すベースプレート上面に設置した変位計 $d 10, d 11, d 15, d 16$ の 鉛直変位を用いて式 4, 式 5 で表される。

$$
\begin{array}{ll}
\text { 角部 : } \delta b=d 16+L_{1} \times{ }_{B} \theta-d 15 & \bullet \cdot(4) \\
\text { フランジ部 }: \delta b=d 11+L_{2} \times{ }_{B} \theta-d 10 & ・ ・(5)
\end{array}
$$

ここで， $L_{1}, L_{2}$ はそれぞれ図 $10(\mathrm{c})(\mathrm{d})$ に示す柱角部と柱フランジ部に おける変位計間距離である。

ベースプレートの変形は，40-8M48D を除きいずれの試験体もアン カーボルト降伏までわずかで，角部とフランジ部の差異も大きくな いことから， ベースプレート下面側への本補強方法が有効であるこ とがわかった。しかし，40-8M48D はアンカーボルト降伏以前より変 形が増加し, 特に角部の変形が大きい。また, 各試験体の $M-{ }_{B} \theta$ 関 係においても，他の試験体がスリップ型の復元力特性を有するのに 対し, 紡錘型を示しており, ベースプレートの面外変形によって復 元力特性に差異が出ている。さらに，最終的にはベースプレート破 断を生じていることから, ベースプレートのメカニズムの把握と余 裕を持った設計が必要であると考える。

なお，40-8M48Uにおいてアンカーボルトが抜け出してしまったこ とに対して，アンカーボルト埋め込夕深さ不足が考えられる。 
本実験のようなアンボンドタイプのアンカーボルトを用いた柱脚 は，アンカーボルトの引抜力の反力を基䃈柱型の補強鉄筋等に期待 するために十分な重ね継手長さが必要となる。このことは，九谷・ 増田の研究 (5で言及されており, アンカーボルトの埋め込み深さに 着目した実験結果から基礎柱型の設計においてアンカーボルトと主 筋の重亦継手長さならびに帯筋量を十分に確保しなければならない と述べられている。下面に補強を施したベースプレートを使用する 場合, 終局時に埋め込まれたリブプレート等が周辺の高強度無収縮 モルタルを破壊し，補強鉄筋の付着耐力が不足する可能性があるこ とから，アンカーボルトの埋め込多深さについてはさらに注意が必 要であり, この点は, 今後の研究課題としたい。

\section{4. 柱脚実験 F E M 解析}

3 章で行った耐荷機構検証実験では, ベースプレート破断を確認す ることができたが，アンカーボルトに対するベースプレートの最適 設計にはベースプレートの変形挙動把握が必要であると考え，FEM 解析によって変形の把握を図ることとした。そこでまずは解析モデ ルの条件設定と妥当性検証のために, ベースプレートの変形が大き かった 40-8M48D 試験体について，素材值を用いた非線形解析を実 施し，実験結果との比較を行う。ここで使用する解析ソフトは MSC. Marc 2008 である。

\section{1 解析モデル}

解析モデルは対称性を考慮した $1 / 2$ モデルで，アンカーボルトを卜

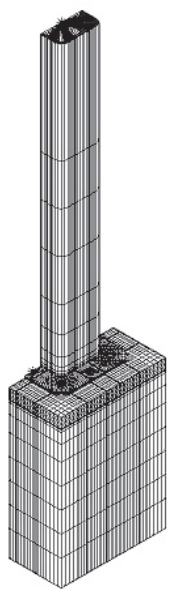

(a) 全体モデル

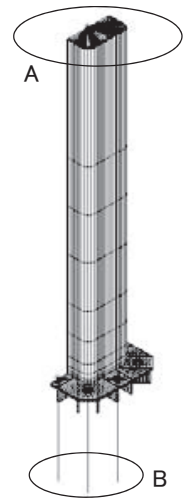

(b)

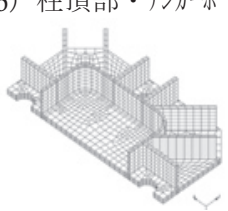

(d) ベー-xプレート

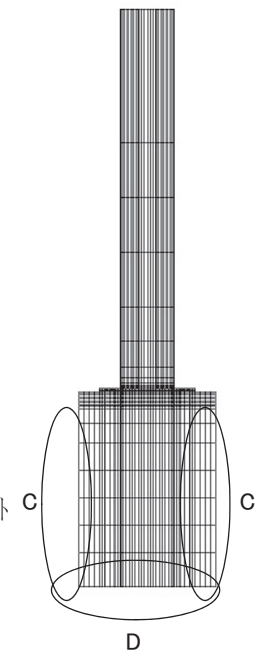

（c）基䃈コンクリート部
図 11 FEM 解析モデル
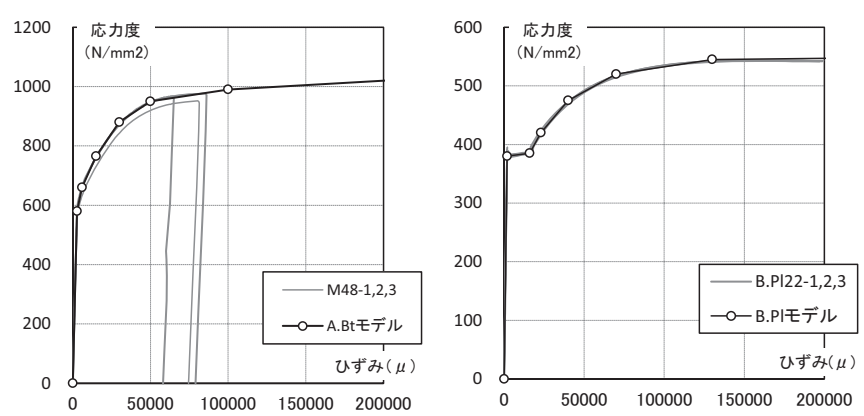

ラス要素, その他要素を 6 面体ソリッド要素とした。解析モデルを 図 11 に示す。

解析モデルは，基礎梁を省略したものでコンクリート高さを実際 の試験体と同じ $1450 \mathrm{~mm}$ とし, 柱材長さもベースプレート下面から 2775mm とした（図 11 (a))。ベースプレート要素は厚さ方向に 4 層, シアコラムの要素を厚さ方向に 2 層としたが, モデル簡略化のために, リブプレートの角部隅切りとスカラップを省略し，シアコラムの高 さをリブプレートと同一とした（図 11(d))。図 11 (b)，(c) に示寸記 号の境界条件は，A：柱材の頂部節点群を剛体化（中心に対して，回 転と並進の自由度を有する）し, 剛体中心に強制水平変位, B : アン カーボルト (トラス要素) の下端節点の鉛直変位を拘束， $\mathrm{C}$ : 基礎梁 の高さまでに該当するコンクリート側面節点群の水平変位を拘束, D: コンクリート下面節点群の鉛直変位を拘束，その他条件として，心゙ ースプレート下面, リブプレート, シアコラムとコンクリートとの 間には接触を考慮したが，摩擦は考慮しない。また，リブプレート 下面とコンクリートは非接触とした。

アンカーボルト頂部は，ナットの 2 面幅で節点群を剛体化した心゙ ースプレートのボルト孔の中心位置とトラス要素のアンカーボルト 上端接点の鉛直変位（引張のみ）を接合している。

\section{2 実験解析結果}

本解析は, ベースプレート, シアコラム, リブプレートの弾塑性 挙動の把握を目的とし, ベースプレート各要素とアンカーボルトを 弾塑性体とした。各素材データは実験素材試験結果に基き, 例とし てアンカーボルトとベースプレートの応力 -ひずタ関係を図 12 に示 す。なお，角形鋼管柱と基礎コンクリートは弾性体とした。これは 柱部材の塑性化は, 解析結果に柱脚自身の挙動によらない水平耐荷 性能の低下を含む恐れがあり，柱脚の挙動をベースプレート上面に

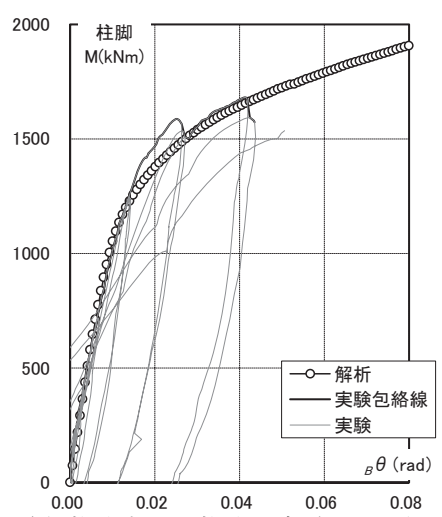

(a) 柱脚部 $M$ - 柱脚回転角 ${ }_{B} \theta$ 関係

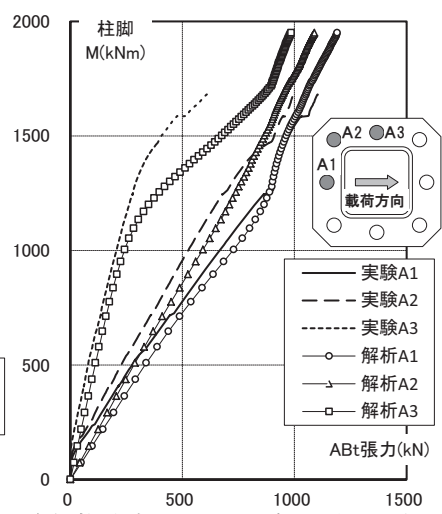

(b) 柱脚部 $M$-アソカーボル張力関係

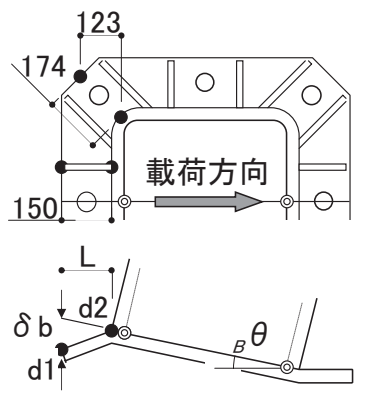

(c) 解析ベースプレート変位計測

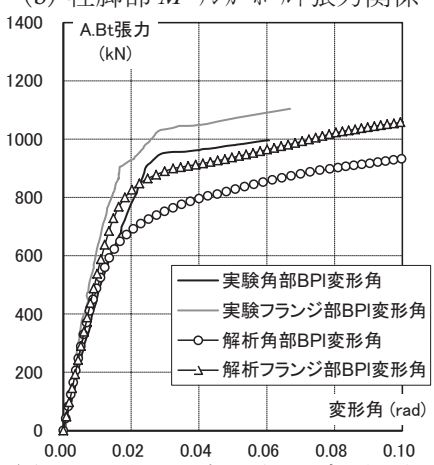

(d) A.Bt 張力 $-ヘ ゙ ー ス 7^{\circ}$ レート変形関係

図 13 FEM 解析結果と実験結果の比較 
表 5 解析モデル一覧 (mm) と解析結果（ベースプレート耐力及び初期剛性）

\begin{tabular}{|c|c|c|c|c|c|c|c|c|c|}
\hline \multirow{2}{*}{ モデル } & \multirow{2}{*}{ 因子 } & \multirow{2}{*}{\begin{tabular}{|c|} 
ベースプレート \\
板厚 \\
\end{tabular}} & \multicolumn{2}{|c|}{ リブプレート } & \multirow{2}{*}{$\begin{array}{c}\text { シアコラム } \\
\text { 板厚 }\end{array}$} & \multicolumn{2}{|c|}{ 全塑性耐力（kN） } & \multicolumn{2}{|c|}{ 初期剛性 $\left(\times 10^{2} \mathrm{kN} / \mathrm{rad}\right)$} \\
\hline & & & 板厚 & 高さ & & 柱フランジ部 & 柱角部 & 柱フランジ 部 & 柱角部 \\
\hline B22R103 & $\begin{array}{c}\text { 実験㑟”ル } \\
\text { (基準) }\end{array}$ & 22 & 12 & 103 & 9 & 795 & 634 & 563 & 425 \\
\hline B22R128 & リブプレート高さ & 22 & 12 & 128 & 9 & $893(1.12)$ & $750(1.18)$ & $611(1.09)$ & 474 (1.12) \\
\hline B22R078 & " & 22 & 12 & 78 & 9 & $680(0.86)$ & $501(0.79)$ & $458(0.81)$ & $343(0.81)$ \\
\hline B28R103 & ベースプレート厚 & 28 & 12 & 103 & 9 & $1,000(1.26)$ & $768(1.21)$ & $623(1.11)$ & $480(1.13)$ \\
\hline B32R103 & " & 32 & 12 & 103 & 9 & $1,132(1.42)$ & $862(1.36)$ & $679(1.21)$ & $523(1.23)$ \\
\hline B32R078 & $\begin{array}{c}\text { リブ・・ } \\
\text { ベースプレート }\end{array}$ & 32 & 12 & 78 & 9 & $1,000(1.26)$ & $715(1.13)$ & $611(1.09)$ & $457(1.08)$ \\
\hline
\end{tabular}

おける回転角で評価しているので, 柱部材の変形量を正確に再現す る必要がないと考えたからである。

解析結果と実験結果の比較を図 13 に示す。単調載荷である解析結 果が，繰返し載荷の実験においても引張力のみを伝達するアンカー ボルトについては包絡線で対応すると考え, 柱脚部モーメント $M$ と 柱脚回転角 ${ }_{B} \theta$ の関係と, 柱脚部モーメント $M$ と各アンカーボルト張 力の関係について実験結果との比較を行った。ここで，解析の柱脚 回転角は図 13 (c) 中@で示した柱材内面で中心線上にある 2 節点の 鉛直方向変位より求め, アンカーボルト張力の実験值はひずみの值 (図 7) から求めたものである。

また，ベースプレートの変形は，単調載荷と繰返し載荷を単純に 比較することは難しいが，アンカーボルトの張力との関係で実験結 果の包絡線との比較を行った（図 $13(\mathrm{~d}))$ 。ベースプレートの変形は 柱角部と柱フランジ部それぞれで比較し, 実験と解析で変位抽出個 所が異なるため計測位置間距離で除した变形角で表した。実験は図 10 (c) に示した変位計位置，解析は図 13 (c) 中 に示寸各部柱外面 と各部ベースプレートの外端における節点の変位を用いて式 4 , 式 5 を用いてベースプレート変形 $\delta b$ を求め, $\delta b$ を節点間距離で除したも のである。

この結果から, 本解析モデルのアンカーボルト弾性範囲における 柱脚部モーメント - 柱脚回転角関係の柱脚剛性やベースプレートに面 外曲げを生じさせる各箇所のアンカーボルト張力が概ね実験結果を 表現できたと考える。そこで、本解析モデルを用いて、リブプレー 卜高さ, ベースプレート厚みを因子としたパラメータ解析を行った。

\section{3 パラメータ解析}

パラメータ解析では，ベースプレートの弾塑性挙動をより明確に するため、アンカーボルトを弾性体とし，その他条件は先の実験解 析と同一である。本解析のモデル一覧を表 5 に示す。先の実験・解 析同様, 柱角部・柱フランジ部に配置された引張側アンカーボルト に対応するベースプレートの変形を求める。ベースプレート変形角 は，図 13 と同じ節点を用いて求め，初期剛性に対して $1 / 3$ 接線剛性 となった時をベースプレート全塑性耐力とし，その時の各部に対応 するアンカーボルト張力の值を表 5 に示す。ここで, ベースプレー 卜全塑性耐力を $1 / 3$ 接線剛性時としたことについて, この方法によっ て定義した耐力が文献のにおかて接合部の各部の降伏が進行し一種 の使用限界に達した状態であると考えられると記述されていること， また塑性耐力の計算值がこの方法による実験值と一致する研究例が 紹介されていることから採用した。表中（）内数值は基準モデルと した実験モデル B22R103 に対する比で，各モデルにおける比を図 14 に示す。また，アンカーボルト張力とベースプレート変形角の関係

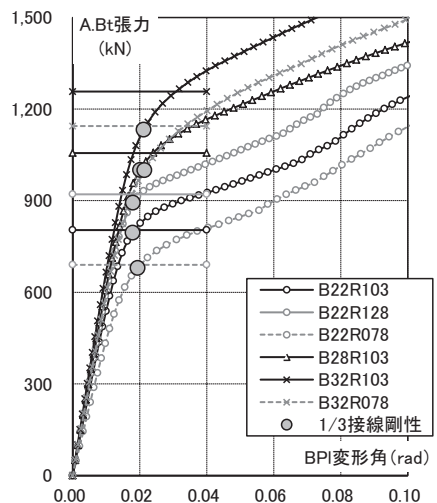

(a) 柱フランジ部

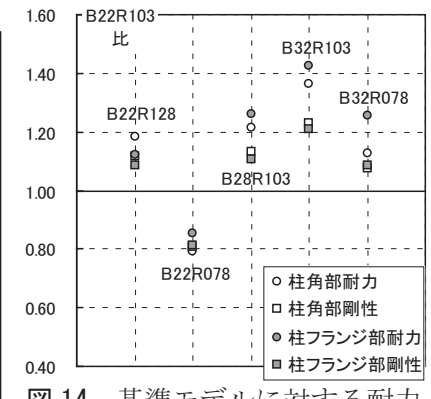

図 14 基準モデルに対する耐力 と剛性の比

図 15 アンカーボルト引張力とベースプレート変形関係

を柱のフランジ部と角部に分けて図 15 に示す。

これらの結果によると，柱角部より柱フランジ部のほうが耐力と 剛性ともに高い。リブプレート高さは各部において耐力と剛性に影 響し，柱角部の方が耐力に影響を大きく受ける。ベースプレート板 厚は柱フランジ部において耐力と剛性への影響が大きく, 特に耐力 への影響が大きい。

5. 柱脚耐荷機構と下面に補強を施した ベースプレートの耐荷機構

柱脚とベースプレートの耐荷機構を推 定しそれぞれの耐力評価式を提案する。

\section{1 柱脚耐荷機構}

（1）柱脚而荷モデルの仮定

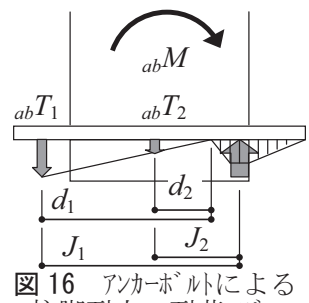

柱脚而时力の而荷モデ

実験における計測結果から柱脚而荷モデルを仮定する。

露出型柱脚は，柱脚部に生じたモーメントに対してアンカーボル ト引張力とベースプレートが基礎柱型コンクリートを圧縮する力で 抵抗する。そこで, 本柱脚においてもアンカーボルトによる柱脚耐 力 ${ }_{a b} M$ の耐荷モデル（図 16）を考えた。このモデルの妥当性を確認 するために，実験における柱頂部水平力から求めた柱脚部モーメン 卜 $M$ と, その時の各列アンカーボルトのひずみ（図 7）から求めた 張力 ${ }_{a b} T$ で上記耐荷モデルに基づき求めた柱脚耐力 ${ }_{a b} M$ を比較する。 ここで，圧縮反力の中心位置を，ベースプレート下に埋め込んだモ 一ルドゲージ（図 18）の柱脚部モーメント毎のひずみ分布の推移（図 17）を参考に圧縮側柱内面とすれば，アンカーボルトによる柱脚而 力は式 6 で求めることができる。

${ }_{a b} M=\sum\left({ }_{a b} T_{n} \times J_{n}\right)$ - ・ (6)

ここで, ${ }_{a b} T, J_{n}$ は引張側第 $n$ 列のアンカーボルト張力と圧縮反力 


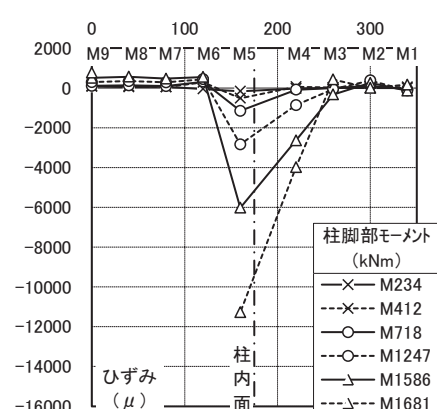

(a) 40-8M48D

図 17

表 6 柱脚降伏耐力の実験值と仮定値

\begin{tabular}{|c|c|c|c|c|}
\hline 試験体名 & ${ }_{B} M_{y}$ (実験值) & ${ }_{a b} M_{y}$ (計算值) & 耐力差 & 埋込深さ \\
\hline $25-4 \mathrm{M} 36$ & 369 & 279 & 90 & $112 \mathrm{~mm}$ \\
\hline $40-8 \mathrm{M} 48 \mathrm{U}$ & 1,773 & 1,424 & 349 & $162 \mathrm{~mm}$ \\
\hline $40-8 \mathrm{M} 48 \mathrm{D}$ & 1,586 & 1,408 & 178 & $130 \mathrm{~mm}$ \\
\hline $40-12 \mathrm{M} 36$ & 1,353 & 1,180 & 173 & $130 \mathrm{~mm}$ \\
\hline
\end{tabular}

中心位置からの距離である (図 16)。

実験において引張側第 1 列目アンカーボルトが全て降伏した時の 柱脚部モーメント（柱脚降伏時モーメント ${ }_{B} M_{y}$ ) と式 6 で引張側第 1 列目アンカーボルトにアンカーボルト降伏耐力を用いて求めた計算 值（柱脚降伏耐力 ${ }_{a b} M_{y}$ ) との比較を表 6 に示寸。

アンカーボルトのひずみを元に求めた柱脚降伏耐力は誤差を含む ものであるが，すべての試験体において柱脚降伏時モーメントがア ンカーボルトによる柱脚降伏耐力に比べかなり大きくなっている。 さらに, シアコラムの埋め込み深さが大きいほどその差も大きい。 この差が，リブプレートをベースプレート下の基礎柱型に埋め込ん だことによる効果であると言える。そこで, 図 16 に示したアンカー ボルトによる耐荷モデルを修正し， リブプレートが基礎柱型に埋め 込まれたことによる効果を考慮した柱脚耐荷モデルを提案する（図 19)。以降では, この耐荷モデルの妥当性を論じる。

（2）柱脚耐力評価式の仮定と妥当性検証

リブプレートを基礎柱型に埋め込んだ柱脚の曲げ耐力 ${ }_{R} M$ をアンカ 一ボルトによる柱脚曲げ耐力 ${ }_{a b, R} M$ とリブプレートが基礎柱型内に埋 込まれたことによる柱脚曲げ耐力 ${ }_{r i b, R} M$ の和で評価することとする。 なお，柱脚に生じたせん断力は，本実験の範囲においてはボルト孔 クリアランスに充填された高強度無収縮モルタルによって圧縮側ア ンカーボルトに伝達されるものと考える。

(1)アンカーボルトによる柱脚耐力

図 17 に示したベースプレート下のひずみ分布に基づき, 圧縮中心 位置を圧縮側柱内面, 中立軸位置を柱心と柱面 の 3/5 の位置とする。また, 各列アンカーボル

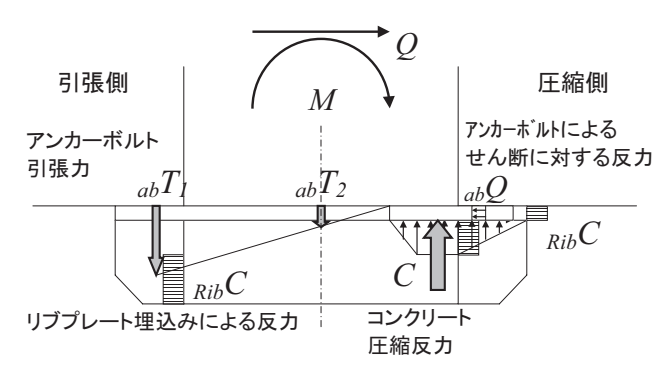

図 19 下面に補強を施した ベースプレートを用いた柱脚の耐荷モデル

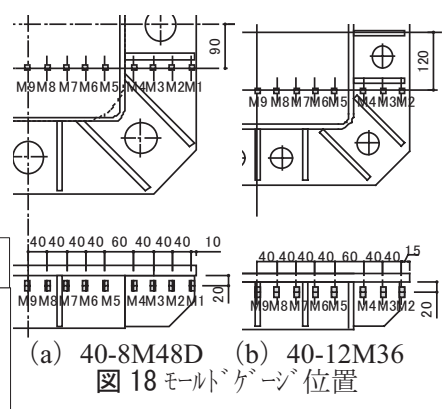

トの引張力は, ベースプレートの 平面保持仮定に基づいて中立軸か らの距離に比例して生じるものと すれば, アンカーボルトによる柱 脚曲げ耐力は式 7 で求めることが できる。

$$
\begin{gathered}
{ }_{a b, R} M=\sum\left(\frac{d_{n}}{d_{1}} \times{ }_{a b} T_{1} \times J_{n}\right) \cdot(7) \\
\text { ここで, }{ }_{a b} T_{1} \text { は引張側第 } 1 \text { 列ア } \\
\text { ンカーボルト張力, } J_{n} \text { と } d_{n} \text { は引張 }
\end{gathered}
$$

側第 $n$ 列アンカーボルトの圧縮反力中心位置からと中立軸からの距 離である（図 19）。

(2)リブプレート埋込みによる柱脚曲げ耐力（図 20)

柱脚に生じた曲げモーメントによって, 基礎柱型から立上った主 筋とフープ筋で補強されたベースプレート周辺の無収縮モルタルに 図 20 に示寸ような水平反力が発生するものと仮定する。ここで, 無 収縮モルタルに生じた水平反力は, 圧縮束によって基礎梁主筋に伝 達されるか, ベースプレート周辺を拘束するフープ筋と基礎柱型主 筋を介して基礎柱型に伝達されるものと推測されるが, 本試験体の ように下面に補強を施したベースプレートの下端を基礎梁主筋に近 く寸るために立上りを出来る限り小さくするとともに, ベースプレ 一ト周辺に十分な補強鉄筋を配置することが必要である。

埋め込まれたシアコラムとリブプレートの幅はほぼベースプレー 卜幅 ${ }_{p l} B$ と同じであり, シアコラムとリブプレートの下端位置もほぼ 同じであることから，埋込まれたリブプレートによる柱脚曲げ耐力 は簡易的に式 8 で表わされる。

$$
{ }_{R i b, R} M=\frac{\left({ }_{s c} h+{ }_{p l} t\right)}{2} \times{ }_{g} \sigma_{y} \times{ }_{p l} B \times{ }_{R i b} J
$$

ここで, ${ }_{p l} B$ はベースプレート幅, ${ }_{s c} h$ はシアコラム高さ, ${ }_{p l} t$ はベー スプレート厚み, $g_{g} \sigma_{y}$ 無収縮モルタル圧縮強度とし, 埋込まれたり ブプレートの回転に伴う水平力の釣り合いから中立軸をシアコラム 高さとベースプレート板厚の和の中間とすれば, 応力間距離 ${ }_{R i b} J$ は, ${ }_{R i b} J=\left({ }_{s c} h+{ }_{p l} t\right) / 2$ となる。

実験におけるアンカーボルト降伏值と無収縮モルタル圧縮強度 ${ }_{g} \sigma_{y}$ 用いて式 7, 式 8 から求めた柱脚降伏曲げ耐力 ${ }_{R} M_{y}$ を表 7 に示す。

表 7 中，（）は本評価式による計算值 ${ }_{R} M_{y}$ をアンカーボルト降伏時 のモーメント ${ }_{B} M_{y}$ で除した值であるが, 概ねよく対応している。また, リブプレート埋込みによる柱脚曲げ而力は表 6 に示寸アンカーボル ト降伏時の柱脚部モーメントとアンカーボルトによる柱脚耐力の差 と比較しても概ね評価できていると考える。ただし, 計算值は無収縮モルタルが圧縮強度に達しているこ とを前提とした柱脚曲げ耐力であり，アンカーボル トが降伏し柱脚の回転角が大きくなれば, ベースプ レート周辺の無収縮モルタルがパンチングシア破壊

表 7 耐荷モデルに基づく柱脚降伏曲げ耐力 $(\mathrm{kN} \cdot \mathrm{m})$

\begin{tabular}{|c|c|c|c|c|}
\hline 試験体名 & ${ }_{a b, R} M_{y}$ & ${ }_{R i b, R} M_{y}$ & ${ }_{R} M_{y}$ & ${ }_{B} M_{y}$ \\
\hline 25-4M36 & 279 & 97 & $376(1.02)$ & 369 \\
\hline 40-8M48U & 1,410 & 257 & $1,667(0.94)$ & 1,773 \\
\hline 40-8M48D & 1,429 & 198 & $1,628(1.03)$ & 1,586 \\
\hline 40-12M36 & 1,128 & 181 & $1,309(0.97)$ & 1,353 \\
\hline
\end{tabular}



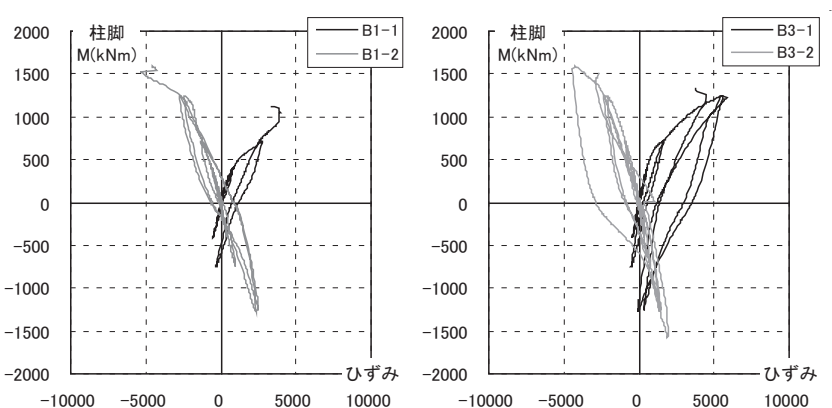

(a) ベースプレートのひずみ
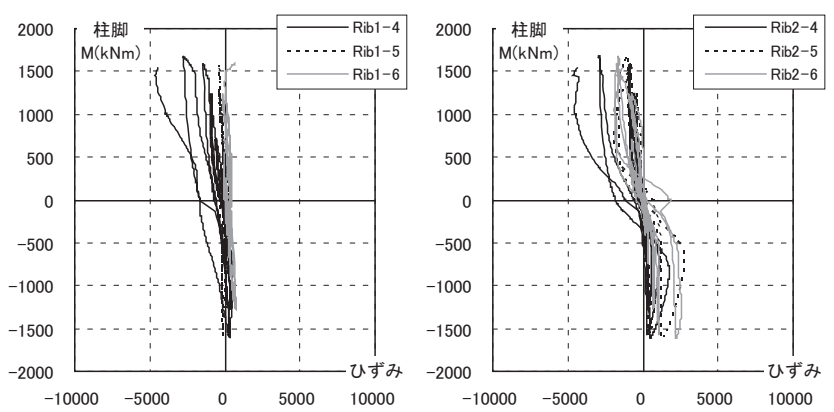

(b) リブプレートのひずみ

図 21 40-8M48D ベースプレート各部のひずみ

を生じ始め，埋込まれたリブプレートによる柱脚耐力に期待するこ とは過大な評価となるため, 注意が必要である。

\section{2 下面に補強を施したベースプレートの耐荷機構}

5.1 節で提案した柱脚耐荷機構モデルはアンカーボルト耐力を求め るに当たってベースプレートに平面保持が成り立つことを前提とし ている。従ってアンカーボルト降伏以前にベースプレートが大きく 変形しないことが肝要である。そこで本節では，下面に補強を施し たベースプレートの耐荷機構を把握し，耐力評価式を提案する。

(1) 変形モデルの仮定

実験の試験体 40-8M48D における，正載荷時に引張側となるべー スプレートの角部とフランジ部のひずみを図 21 に示す。また，それ ぞれのゲージの配置を図 22 に示す。

ベースプレートのひずみは上面において引張ひずみ，下面が圧縮 ひずみとなっていることから, ベースプレートにアンカーボルト引 張力による曲げが生じていることがわかる。また, 正載荷時にアン カーボルト引張側となるリブプレートのひずみは, 正載荷時に圧縮 ひずみが生じ，負載荷時には引張ひずみを生じている。

補強を上面に施したベースプレートの設計 ${ }^{3)}$ として, 引張側をべ ースプレートの面外曲げで，圧縮側をリブプレートと柱面とのせん 断耐力で検討する方法があるが, 図 21 に示す今回柱脚実験を実施し たベースプレート各部のひずみから, 引張側においてベースプレー 卜面外曲げとリブプレートの圧縮抵抗を累加して評価できるものと 考え，図23に示す心゙ー スプレートの変形モデル を仮定した。

ここで，無収縮モルタ ルの充填によって拘束さ れているシアコラムは, 柱材およびベースプレー トと一体化した回転変

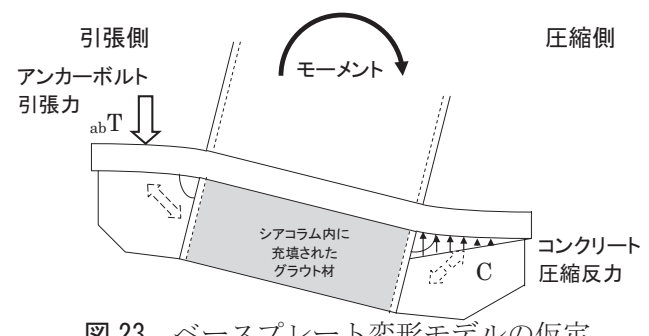

図 23 ベースプレート変形モデルの仮定

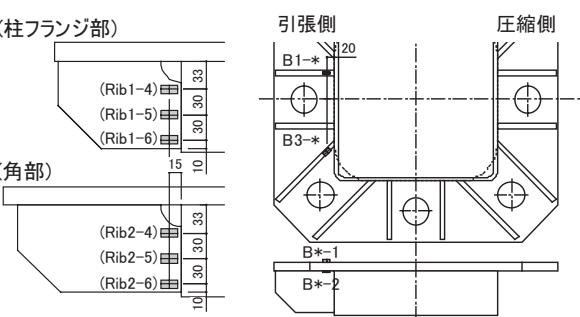

図 22 ベースプレートひずみ計測位置
形をすると仮定する。こ れは実験終了後のベース プレート董側観察におい て, シアコラム内に充填 された高強度無収縮モル タルに大きな損傷がなか ったことに基づく。

これらの仮定した変形 モデルに基づき，下面に補強を施したベースプレートの耐荷モデル と耐力評価式を以下に示す。

（2）耐荷モデル及び耐力評価式

図 23 で仮定したベースプレート変形モデルにおいて, ベースプレ 一トの変形が柱脚変形に大きく影響を及ぼす引張側について, 有効 断面等を定め耐力評価式を提案する。角屋らの研究 7) 参考に, 柱 角部，柱フランジ部それぞれに配置されたアンカーボルトに生じた 引張力に対して，ベースプレートが全塑性状態になる時の耐荷機構 モデルを図 24 のように仮定し，検討を行うこととする。この耐荷機 構モデルでは, 柱脚に曲げが作用した際にアンカーボルトに生じる 引張力 ${ }_{a b} T$ に対して, ベースプレートの面外曲げとリブプレートの圧 縮及びせん断で抵抗すると考える。そこで, 面外曲げに対するべー スプレート有効断面が柱材もしくはシアコラムの溶接余盛を考慮し た位置にあるとして，下面に補強を施したベースプレートの全塑性 耐力時の ${ }_{a b} T_{p}$, すなわち ${ }_{b p} P_{p}$ が， ベースプレートの面外曲げ抵抗耐力 ${ }_{p l} M_{p}$ による偶力とリブプレートのせん断抵抗耐力 ${ }_{R i b} Q_{y}$ の和であると すると式 9 で表される。

$$
{ }_{b p} P_{p}=\frac{{ }_{p l} M_{p}}{{ }_{a b} L}+{ }_{R i b} Q_{y}
$$

ここで, ${ }_{a b} L$ は有効断面からアンカーボルト張力の作用点までの距 離とし，作用点はベースプレートのボルト孔の内面とする。

なお, 式 9 中のベースプレートの面外曲げ抵抗耐力 ${ }_{p l} M_{p}$ とリブプ レートのせん断抵抗耐力 ${ }_{R i b} Q_{y}$ は, 図 24 (a) の耐荷モデルに従って, 以下の（i）（ii）の要領で導出される。

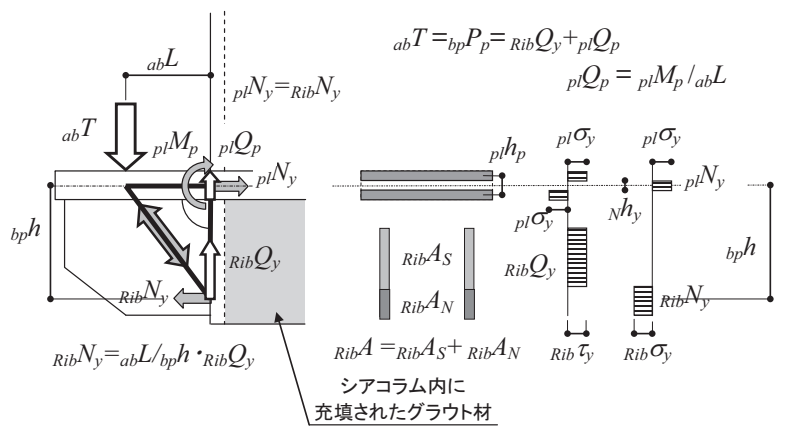

（a）耐荷モデル

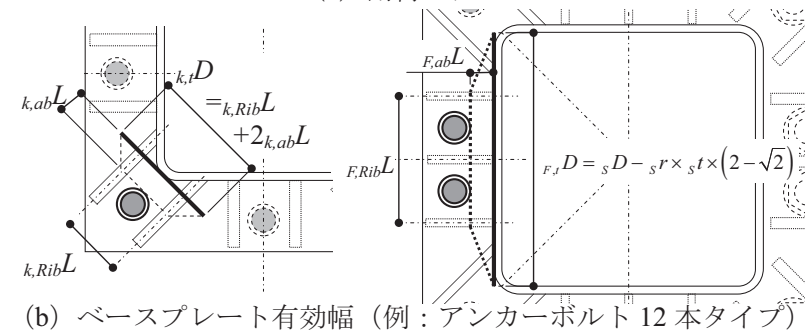

図 24 ベースプレート耐荷モデル 
( i ) リブプレートのせん断抵抗耐力 ${ }_{R i b} Q$

全塑性耐力時にはリブプレート下端から圧縮降伏状態に達すると 仮定し, リブプレート断面内で下端から圧縮負担領域とせん断負担 領域を分けて考えることとする（図 $24(\mathrm{a}))$ 。リブプレートのシアコ ラム面における鉛直方向力（せん断力）と水平方向力（圧縮力）を それぞれ ${ }_{R i b} Q_{y}, R_{R i b} N_{y}$, 圧縮負担領域の鉛直方向中心からベースプレー 卜板厚方向中心までの距離を ${ }_{b p} h$ とおくと, これらの間には, 幾何学 的な関係から，

$$
{ }_{R i b} N_{y}=\frac{{ }_{a b} L}{{ }_{b p} h} \times{ }_{R i b} Q_{y}
$$

が成り立つ。ここで,

$$
\begin{aligned}
& { }_{R i b} N_{y}={ }_{R i b} A_{N} \times{ }_{R i b} \sigma_{y} \\
& R i b
\end{aligned}
$$

であり, ${ }_{R i b} \sigma_{y}$ はリブプレートの降伏点, ${ }_{R i b} \tau_{y}$ はリブプレートのせん 断降伏応力 $\left(={ }_{R i b} \sigma_{y} / \sqrt{3}\right),{ }_{R i b} A$ は耐荷モデルに関わるリブプレート 全断面積, ${ }_{R i b} A_{N}$ はリブプレートの圧縮負担領域の面積, ${ }_{R i b} A_{S}$ リブプ レートのせん断負担領域の面積である。ここで, ${ }_{R i b} A$ として算定する リブプレート枚数は, 本研究で対象としたディテールにおいて柱角 部で 2 枚とし, 柱フランジ部では柱フランジ部に配置されたアンカ 一ボルトを挟むように配置されたリブプレートのみとする（つまり， 40-8M48U,D で 2 枚, 40-12M36 で 3 枚)。

なお, 式 10 中の, ${ }_{b p} h$ は未知数であるが, ベースプレートの全塑性 耐力時のアンカーボルト張力 ${ }_{a b} T_{p}$ によってベースプレートに生じる 曲げモーメント ${ }_{\text {Ribbp }} M_{p}$ に関して次式を成り立たせるように定まって いる必要がある。

$$
{ }_{R i b b p} M_{p}={ }_{a b} T_{p} \times{ }_{a b} L={ }_{p l} M_{p}+{ }_{R i b} N_{y} \times{ }_{b p} h
$$

さらに, せん断力に着目すると, 式 (10-2), (10-3) から, 圧縮負担 面積 ${ }_{R i b} A_{N}$ は ${ }_{b P} h$ を用いて次式で表される。

$$
{ }_{R i b} A_{N}=\frac{{ }_{a b} L \times_{R i b} A}{{ }_{b p} h \times \sqrt{3}} /\left(1+\frac{{ }_{a b} L}{{ }_{b p} h \times \sqrt{3}}\right)
$$

以上に記した式 (10), (11), (12) を満たす ${ }_{b p} h$ を得るには収束計算 が必要であるが, 得られた ${ }_{b P} h$ から ${ }_{R i b} N_{y},{ }_{R i b} Q_{y}$ を算定できる。

（ii） ベースプレートの面外曲げ抵抗耐力 ${ }_{p l} M_{p}$

上記（i ）で得られた ${ }_{R i b} N_{y}$ に釣合うように, ベースプレートには 引張力が作用する。ベースプレートの曲げ耐力は, この引張力の存 在により低減されることにことになる。ベースプレート面外曲げ抵 抗耐力 ${ }_{p l} M_{p}$ は, ベースプレートの有効断面の幅 $D$ を用いて以下の式 13 で得られる。

$$
\begin{array}{cc}
{ }_{p l} M_{p}={ }_{p l} \sigma_{y} \times{ }_{t} D \times\left({ }_{p l} t-{ }_{N} h_{y}\right) \times \frac{{ }_{p l} h_{p}}{2} & \cdots(13) \\
{ }_{N} h_{y}={ }_{R i b} N_{y} /\left({ }_{p l} \sigma_{y} \times{ }_{t} D\right) & \cdots(13-1) \\
{ }_{N} h_{p}={ }_{p l} t-\left({ }_{p l} t-{ }_{N} h_{y}\right) / 2=\left({ }_{p l} t+{ }_{N} h_{y}\right) / 2 & \cdots \cdot(13-2)
\end{array}
$$

ここで， ${ }_{p l} \sigma_{y}$ はベースプレート降伏点 $\left(\mathrm{N} / \mathrm{mm}^{2}\right)$ である。なお， ベー スプレートの有効断面の幅 $D$ は, 柱角部がアンカーボルトをはさん で配置されたリブプレートから 45 度の方向に広がると考えて定める ものとし, 柱フランジ部はシアコラム角の曲面頂点を結ぶ水平投影 距離として以下の式で表される(図 $24(\mathrm{~b})$ )。

柱角部 : ${ }_{k, t} D={ }_{k, R i b} L+2_{k, a b} L$,
柱フランジ部 : ${ }_{F, t} D={ }_{S} D-{ }_{S} r \times{ }_{S} t \times(2-\sqrt{2})$ . . (13-4) ここで, $k_{k, R i b} L$ は柱角部のリブプレート間隔, $k_{k, a b} L$ は柱角部直近アンカ 一ボルト孔内面縁からシアコラム角部までの距離, ${ }_{s} D$ はシアコラム 外径, ${ }_{s} r \times{ }_{s} t$ はシアコラム角部曲面半径で, ${ }_{s} r$ はシアコラムの材質が BCR295 の場合に 2.5 , BCP325 の場合に $3.5, s_{s}^{t}$ がシアコラム厚である。 (3) 耐力評価式の妥当性検証

実験結果や FEM 解析結果と比較を行い, 耐力評価式の妥当性を検 証する。

まず，柱脚実験試験体の形状と素材值を代入して求めたベースプ レート各部全塑性耐力の計算結果を実験結果と比較する。ここで, 試験体の角部では, 柱材とベースプレート下面のシアコラムの板厚 が異なる場合に鋼管角部の曲げ半径が異なることから,${ }_{a b} L$ の算出に おいて, シアコラムの曲げ半径を使用した。また, 溶接余盛は,408M48D, 40-12M36 で実測值（角部：シアコラム溶接余盛 $9 \mathrm{~mm}$, 柱フ ランジ部：柱材溶接余盛 $7 \mathrm{~mm} ）$ を用い，他は柱角部でシアコラム板 厚の $1 / 2$, 柱フランジ部で柱材板厚の $1 / 3$ と仮定した。なお，実験に おけるリブプレートには, 図 24 に示寸ようにベースプレートとシア コラムの溶接線との干渉を避けるためのスカラップを施しており, 式 10 におけるリブプレート断面積 ${ }_{R i b} A$ を求める際に有効断面位置に おけるスカラップ寸法（表 8）をリブプレート高さから減じている。

このようにして求めた各試験体における計算值を表 8 に示し, 各 部アンカーボルト引張力とベースプレート変形関係における比較を 図 25 に示寸。

40-12M36において，計算值がフランジ部でやや過小評価となって いる。しかし，他の試験体では明確なベースプレート変形が見られ なかったため, 4 章で行った FEM 解析のアンカーボルト弾性とした パラメータ解析の結果と比較を行う。ここで，4 章でも述べた通り， 解析モデルはシアコラム角部の曲げ半径は柱材と同一で，溶接余盛 もスカラップも考慮していない。

耐力評価式に FEM 解析モデルの形状と素材值を代入して求めた心゙ ースプレート各部全塑性耐力の計算結果と表 5 に示す FEM 解析にお ける $1 / 3$ 接線剛性時耐力を比較した結果を表 9 に示す。表中, 計算値 の（）は，FEM 解析值に対する比率である。また，先に紹介した図 15 においてこの計算値の比較をしている。

計算值は，各部ともにリブプレートの高さの変化などに概ね良い 対比を示しているが， ベースプレートがリブプレート高さに対して

表 8 柱脚実験試験体ベースプレート全塑性耐力 $(\mathrm{kN})$

\begin{tabular}{|c|r|r||c|}
\hline 試験体名 & 柱フランジ部 & 柱角部 & 功ラップ $^{-1}$ \\
\hline $25-4 \mathrm{M} 36$ & - & 634 & $30 \mathrm{~mm}$ \\
\hline $40-8 \mathrm{M} 48 \mathrm{U}$ & 1,416 & 985 & $40 \mathrm{~mm}$ \\
\hline $40-8 \mathrm{M} 48 \mathrm{D}$ & 829 & 793 & $25 \mathrm{~mm}$ \\
\hline $40-12 \mathrm{M} 36$ & 914 & 553 & $25 \mathrm{~mm}$ \\
\hline
\end{tabular}

表 9 耐力評価計算值と FEM 解析結果 $(\mathrm{kN})$

\begin{tabular}{|c|r|r|r|r|}
\hline \multirow{2}{*}{ モデル } & \multicolumn{2}{|c|}{ 柱フランジ部 } & \multicolumn{2}{c|}{ 柱角部 } \\
\cline { 2 - 6 } & 計算值 & 解析值 & 計算值 & 解析值 \\
\hline B22R128 & $921(1.03)$ & 893 & $754(1.01)$ & 750 \\
\hline B22R103 & $804(1.01)$ & 795 & $637(1.01)$ & 634 \\
\hline B22R078 & $690(1.01)$ & 680 & $523(1.04)$ & 501 \\
\hline B28R103 & $1,056(1.06)$ & 1,000 & $787(1.02)$ & 768 \\
\hline B32R103 & $1,257(1.11)$ & 1,132 & $906(1.05)$ & 862 \\
\hline B32R078 & $1,144(1.14)$ & 1,000 & $792(1.11)$ & 715 \\
\hline
\end{tabular}




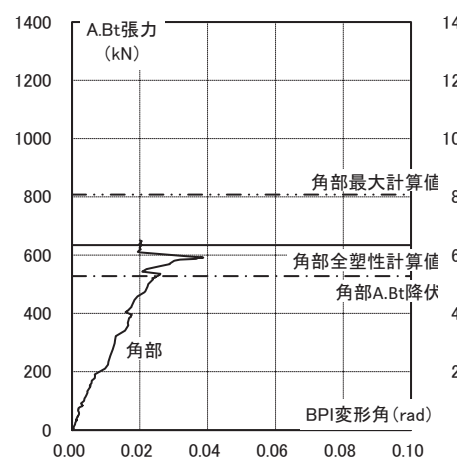

(a) $25-4 \mathrm{M} 36$

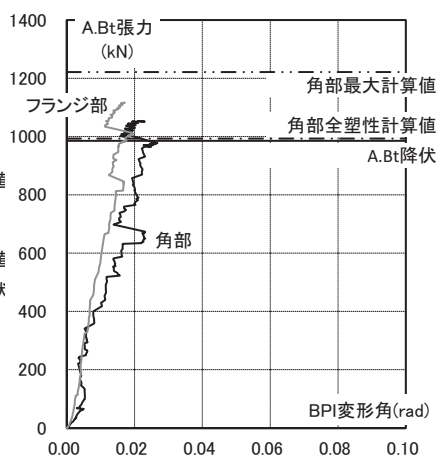

(b) $40-8 \mathrm{M} 48 \mathrm{U}$

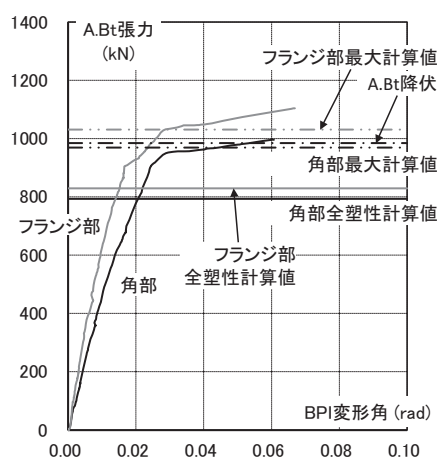

(c) 40-8M48D

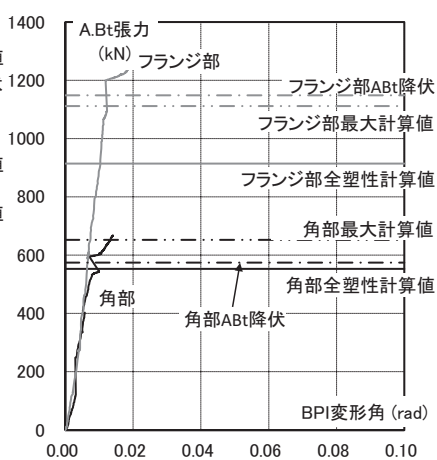

(d) $40-12 \mathrm{M} 36$

表 10 ベースプレート最大耐力の検討 $(\mathrm{kN})$

\begin{tabular}{|c|c|c|c|c|c|}
\hline \multirow[b]{2}{*}{ 試験体名 } & \multicolumn{2}{|c|}{ 柱フランジ部 } & \multicolumn{2}{|c|}{ 柱角部 } & \multirow[b]{2}{*}{ 最終状況 } \\
\hline & $\begin{array}{c}\text { 最大耐力 } \\
\text { (計算値) } \\
F_{p l p} P_{u}\end{array}$ & $\begin{array}{c}\text { A.Bt } \\
\text { 最大張力 } \\
{ }_{F a b} T_{u}\end{array}$ & $\begin{array}{c}\text { 最大耐力 } \\
\text { (計算値) } \\
K_{k, p l} P_{u}\end{array}$ & $\begin{array}{c}\text { A. Bt } \\
\text { 最大張力 } \\
{ }_{K, a b} T_{u}\end{array}$ & \\
\hline $25-41$ & - & - & $808 \quad(1.24)$ & 650 & 基礎圧壊 \\
\hline $40-8 \mathrm{M} 48 \mathrm{U}$ & $1,853 \quad(1.59)$ & 1,168 & $1,221 \quad(1.14)$ & 1,072 & 定着破壊 \\
\hline 40-8M48D & $1,031 \quad(0.94)$ & 1,101 & $969(0.98)$ & 994 & BP1 破断 \\
\hline $40-12 \mathrm{M} 36$ & $1,111 \quad(0.78)$ & 1,422 & $652 \quad(0.95)$ & 686 & $\mathrm{BPl}$ 破断 \\
\hline
\end{tabular}

\section{6. まとめ}

露出型柱脚のベースプレート下面側への補強方法について実大柱 脚実験を行い, 効果的な補強方法の提案とそのメカニズムを検証し た。本研究において明らかになったことを以下に示す。

1）本提案のベースプレート補強方法は，内部に無収縮モルタルを充 填したシアコラムとベースプレートにそれぞれ垂直に取り付けら れたリブプレートが，ベースプレートの面外変形を抑える役割を 果たすとともに，圧縮およびせん断で抵抗することによりべース プレートの曲げ耐力向上に有効であることがわかった。

2）本提案の下面側へのリブプレートによる補強を施したベースプレ ートを用いた柱脚の曲げ耐力について，アンカーボルトによる抵 抗とベースプレート下面側に施したリブプレートなどを基礎柱型 に埋め込んだことによる抵抗によって評価できることを実験によ り確認した。

3）本提案の補強方法による補強を下面に施した場合のベースプレー トの耐荷機構を仮定し，実験および FEM 解析によってその妥当性 検証を行い，概ね評価できた。

4）リブプレート高さはベースプレートの曲げ耐力剛性に影響し，柱 角部において耐力に与える影響が大きい。また，柱フランジ部に おいてはベースプレート厚みが曲げ耐力に与える影響が大きい。

5）露出型柱脚において，アンカーボルトの降伏に先行してベースプ レートが大きく変形しないことが重要であるが，下面に補強を施 したベースプレートを実用化するに当たって，提案したベースプ レート耐力評価式が有効であることを確認した。

9-式 13 において ${ }_{p l} \sigma_{y},{ }_{p l} N_{y},{ }_{p l} Q_{y}$ を ${ }_{p l} \sigma_{u},{ }_{p l} N_{u},{ }_{p l} Q_{u}$ に置き換えて得ら れる。

仮定したモデルを用いて, 柱脚実験試験体におけるベースプレー 卜最大耐力計算值を実験におけるアンカーボルトの最大引張力と比 較した結果を, 表 10 と図 25 のアンカーボルト張力ーベースプレー 卜変形角関係に示す。ここで, 表中の（）はベースプレート最大耐 力值をアンカーボルト最大引張力で除した值である。なお, ベース プレート引張強さには素材試験結果を用いた。

これらの結果からベースプレート破断を生じた試験体で, アンカ 一ボルト最大引張力がベースプレートの最大耐力を上回っており, ベースプレートの最大耐力を評価できていると考える。ただし，4012M36 の柱フランジ部が 0.78 と過小評価となっていることから柱フ ランジ部にアンカーボルトが複数本配置される場合の評価に課題が 残る。

\section{参考文献}

1）小川壽，足立拓郎： $\mathrm{L}$ 型平板の応力集中について（第 4 報 リブ補強による 変形抑制効果), 宇部工業高等専門学校研究報告, 第 20 号, 1975.3

2）五十嵐定義, 脇山公三, 井上一朗, 松本竹二, 村瀬良秀: 高力ボルト鋼管 フランジ継手の極限設計法に関する研究 その 2 リブ・リング付き継手, 日本建築学会構造系論文報告集, 第 358 号, pp.71-82, 1985.12

3）日本建築学会：鋼構造接合部設計指針，日本建築学会，2006.3

4）秋山宏, 黒沢稔, 和国信之, 西村功: 鋼構造露出柱脚のせん断耐力ーアン カーボルト, シアプレートのせん断抵抗一, 日本建築学会論文報告集, 第 338 号, pp.71-76, 1984.4

5）九谷和秀, 増田貴志: 鉄骨柱脚部の力学性状に関寸る実験的研究 アンカ 一ボルトの埋込み深さ（その1），日本建築学会研究報告 九州支部 1 , 構 造系 (34), pp.401-404, 1994.3

6）独立行政法人建築研究所, 社団法人日本鉄鋼連盟：鋼構造建築物の構造 性能評価試験法に関する研究 委員会報告書, 2002.4

7）角屋治克, 渡辺亨, 鈴木正裕, 萩野毅, 染谷友英：露出型柱脚の力学的性 状に関する実験的研究, 鋼構造年次論文報告集, 第 6 巻, pp.261-268, 1998.11 